\author{
Никитина Ю. В.*, Топникова Е. В., Лепилкина О. В., Кашникова О. Г. \\ Всероссийский научно-исследовательский институт маслоделия и сыроделия, Углич, Ярославская область, Россия
}

КЛЮЧЕВЫЕ СЛОВА:

лактазная недостаточность, низколактозные молочные продукты, безлактозные молочные продукты,

$\beta$-галактозидаза, особенности технологий, методы контроля

Received 10.04.2021

Accepted in revised 05.06.2021

Accepted for publication 25.06.2021

\section{АННОТАЦИЯ}

Рассмотрены особенности технологий низко- и безлактозных молочных продуктов, предусматривающие проведение специальных операций по гидролизу лактозы или удалению ее с помощью ультра- или нанофильтрации с последующим гидролизом остаточного количества. Представлена молочная продукция, изготовляемая по этим технологиям в разных странах, и предприятия, лидирующие в этой сфере производства. Проведен анализ методов, применяемых для определения количественного содержания остаточной лактозы в низко- и безлактозных молочных продуктах: ферментативные, ВЭЖХ, HPAEC-PAD, амперометрические биосенсоры, рамановская спектроскопия. В связи с потребностью молочной промышленности в методах анализа для определения лактозы в молоке и молочных продуктах с низким или безлактозным содержанием, группа заинтересованных сторон АОАС по стратегическим методам анализа пищевых продуктов утвердила Стандартные требования к эффективности биосенсорных методов (SMPR ${ }^{\circledR}$ ) 2018.009. Данные требования введены для количественного определения лактозы в молоке, а также в молочных и молокосодержащих продуктах с низким содержанием лактозы или ее полным отсутствием. Биосенсорный метод рекомендован для использования в качестве официального метода АОАС первого действия. Наряду с этим целесообразно использовать в статусе международного стандартного метода анализа для определения лактозы в молоке с низким или безлактозным содержанием высокоэффективную жидкостную хроматографию (ВЭЖХ) с масс-спектрометрическим детектированием, а также высокоэффективную анионообменную хроматографию с импульсным амперометрическим детектированием (HPAEC-PAD).

\title{
TECHNOLOGICAL AND METHODOLOGICAL ASPECTS OF PRODUCTION OF LOW- AND LACTOSE-FREE DAIRY PRODUCTS
}

\author{
Julia V. Nikitina*, Elena V. Topnikova, Olga V. Lepilkina, Olga G. Kashnikova \\ All-Russian Scientific Research Institute of Butter- and Cheesemaking, Uglich, Yaroslavl Region, Russia
}

KEY WORDS:

lactase deficiency, lowlactose dairy products, lactose-free dairy products, $\beta$-galactosidase, technology features, control methods

\begin{abstract}
The features of technologies for low- and lactose-free dairy products, which provide for special operations to hydrolyze lactose or remove it using ultra- or nanofiltration followed by hydrolysis of the residual amount, are considered. Dairy products manufactured using these technologies in different countries as well as enterprises leading in this field of production are presented. The analysis of the methods used to determine the quantitative content of residual lactose in low- and lactose-free dairy products is carried out: enzymatic, HPLC, HPAEC-PAD, amperometric biosensors, Raman spectroscopy. Due to the dairy industry's need for analytical methods for the determination of lactose in milk and dairy products with low- or lactose-free content, the AOAC Stakeholder Group on Strategic Food Analysis Methods approved Standard Performance Requirements for Biosensor Methods (SMPR ${ }^{\circledR}$ ) 2018.009. These requirements were introduced for the quantitative determination of lactose in milk as well as in dairy and milk-containing products with a low or no lactose content. The biosensor method is recommended for use as the official first step of AOAC method. Additionally, it is advisable to use high performance liquid chromatography (HPLC) with mass spectrometric detection, as well as high performance anion exchange chromatography with pulsed amperometric detection (HPAEC-PAD) as an international standard method of analysis for the determination of lactose in milk with low- or lactose-free content.
\end{abstract}

ДЛЯ ЦИТИРОВАНИЯ: Никитина, Ю.В., Топникова, Е.В., Лепилкина, О.В., Кашникова, О.г. (2021). Технологические и методические аспекты производства низко- и безлактозных молочных продуктов. Пищевые системы, 4(2), 144-153. https://doi.org/10.21323/2618-9771-2020-4-2-144-153
FOR CITATION: Nikitina, J.V., Topnikova, E.V., Lepilkina, O.V., Kashnikva, O.G. (2021). Technological and methodological aspects of the production of low- and lactose-free dairy products. Food systems, 4(2), 144-153. https://doi. org/10.21323/2618-9771-2021-4-2-144-153 


\section{1. Введение}

Коровье молоко представляет собой богатую питательными веществами, химически сложную биожидкость, состоящую из множества различных компонентов $[1,2,3]$. В настоящее время с помощью современных методов исследования в составе коровьего молока идентифицировано 2355 химических веществ. В химическом составе коровьего молока преобладают углеводы (в основном лактоза, а также глюкоза и галактоза), неорганические ионы (калий и кальций), органические кислоты и аминосодержащие соединения (креатинин, холин и мочевина). В меньшем количестве содержатся витамины, триглицериды, ди- и моноглицериды, жирные кислоты, аминокислоты и другие биологически активные соединения [3].

Приятный, сладковатый привкус молока обусловлен наличием в его составе лактозы - молочного сахара. В коровьем молоке в среднем содержится 4,7\% лактозы с максимальным диапазоном колебаний от 4,5\% до 5,2\% [2]. Содержание молочного сахара в молоке зависит от сезона года, стадии лактации, количества соматических клеток и не связано с породой коровы, удоем, содержанием молочного жира и белка $[4,5]$.

Лактоза выполняет важную физиологическую функцию для пищеварения: стимулирует развитие молочнокислой микрофлоры в кишечнике, что в итоге улучшает усвоение организмом кальция и фосфора, а также подавляет развитие гнилостной микрофлоры, выделяющей токсичные вещества. Кроме того, она способствует укреплению иммунитета, участвует в синтезе жиров, белков, витаминов, внутриклеточном обмене, в работе всех важнейших органов - сердца, печени, почек, головного мозга и нервной системы. Благодаря медленному усвоению лактозы в организме, это соединение обеспечивает человека энергией на длительное время, не повышая при этом значительно уровень сахара в крови, а также способствует регенерации клеток, благотворно влияет на состояние кожи, волос и ногтей [6].

Нельзя переоценить значимость лактозы в питании детей, поскольку она является единственным источником крайне важного для растущего организма сахара - галактозы, образующейся при ее расщеплении. Галактоза используется для синтеза галактолипидов, в том числе цереброзидов, необходимых для формирования центральной нервной системы и миелинизации нервных волокон [7,8,9]. В присутствии лактозы увеличивается абсорбция кальция из грудного молока и молочных смесей [10].

Однако части населения планеты противопоказано употребление в пищу молока и молочных продуктов из-за непереносимости содержащейся в них лактозы $[11,12,13]$. Корень проблемы лежит в следующем.

Молоко млекопитающих с точки зрения эволюции является сугубо детским питанием, необходимым для вскармливания потомства в первые один-два года жизни. Поэтому изначально у всех человеческих детенышей после периода вскармливания естественным образом утрачивалась или снижалась способность вырабатывать лактазу. Однако с развитием на планете животноводства началась эволюция генов у людей, разводивших молочных животных и постоянно употреблявших в пищу молоко и изготовленные из него продукты. Постепенно в их организме произошла мутация гена, отвечающего за выработку фермента лактазы. При этом данная мутация гена встречается не у всех людей, что и является причиной возникновения у них непереносимости лактозы $[14,15]$.

В публикации J.-L. Vilotte [16] описано несколько попыток создания трансгенных мышей, дающих молоко с модифицированными углеводными композициями. Производство молока с низким содержанием лактозы in vivo было достигнуто у трансгенных мышей с использованием различных страте- гий. В зависимости от молекулы, которая была нацелена на этот метаболический путь, наблюдались различные физиологические последствия в организме животного. Авторы делают вывод о том, что экспрессия лактазы, достигнутая искусственным изменением генотипа жвачных животных при помощи генной инженерии, является привлекательным подходом для производства молока, адаптированного для людей, страдающих гиполактазией. И в перспективе можно было бы ожидать, что скоро для этой цели будут выведены трансгенные жвачные животные.

В данной статье не рассматривается такой подход в качестве перспективного, т. к. это дорогая и неэффективная стратегия, вызывающая много споров, в том числе этической направленности $[17,18,19]$.

Наиболее целесообразным путем решения проблемы улучшения жизни людей, страдающих лактазной недостаточностью, является производство низко- и безлактозных молочных продуктов, ассортимент которых в последние годы расширяется.

Настоящий обзор содержит сведения об особенностях технологий производства низко- и безлактозных молочных продуктов с учетом потребительских предпочтений в различных странах.

\section{2. Основная часть}

\section{1. Технологические аспекты получения}

низко- и безлактозных молочных продуктов

Для нормального усвоения лактозы организмом человека требуется ее расщепление на моносахариды (глюкозу и галактозу). В организме человека это обеспечивает фермент лактаза ( $\beta$-галактозидаза), вырабатываемый пищеварительной системой. При дефиците в организме человека фермента лактазы развивается лактазная недостаточность - гиполактазия, а при ее полном отсутствии - алактазия. При гиполактазии и тем более алактазии лактоза, попадая в кишечник в нерасщепленном виде, вызывает осмотическую диарею, что существенно снижает качество жизни человека [20]. Признаками непереносимости лактозы являются вздутие, диарея, тяжесть или боль в кишечнике после приема в пищу молока или иных молочных продуктов (исключение составляют твердые и полутвердые сыры) [21,22].

Различают первичную (врожденную) и вторичную лактазную недостаточность. Врожденная лактазная недостаточность представляет серьезную угрозу для жизни новорожденных, поскольку молоко для них является единственным продуктом питания [23]. Она, как правило, характеризуется полным отсутствием лактазы и встречается крайне редко [24]. В европейских странах, в том числе в России, гиполактазия новорожденных наблюдается в 0,002\% случаев. В странах Азии и Африки гиполактазия у детей включая новорожденных, встречается значительно чаще [25].

Вторичный дефицит лактазы может возникнуть в результате повреждения тонкой кишки, например, при остром гастроэнтерите, разрастании тонкой кишки, химиотерапии или по какой-либо другой причине повреждения слизистой оболочки тонкого кишечника и может проявиться в любом возрасте [26,27].

При первичной лактазной недостаточности в основе лечения пациента лежит снижение количества лактозы в пище вплоть до полного ее исключения. При вторичной (приобретенной) - назначается лечение с целью устранения основной причины заболевания с ограничением лактозы в рационе питания [28].

Уменьшить симптомы лактазной недостаточности возможно, совмещая прием в пищу молока или иных молочных продуктов, с другой пищей, т. к. время прохождения лактозы, через кишечник увеличится [22,29]. 
В Таблице 1 показано содержание лактозы в основных молочных продуктах, без которых трудно представить рацион питания любого человека.

Изготовленные из молока молочные продукты в той или иной степени сохраняют молочный сахар в своем составе. При технологической переработке молока лактоза переходит в готовый продукт, иногда при этом трансформируясь в другие соединения. Полностью отсутствует она лишь в зрелых полутвердых и твердых сырах, во время созревания которых под воздействием фермента лактазы, продуцируемого заквасочными культурами микроорганизмов, полностью переходит в молочную кислоту, ароматические вещества и газы, формирующие органолептические свойства сыра. Однако в полной мере относить полутвердые и твердые сыры к категории безлактозных продуктов не совсем корректно. Это связано с тем, что в технологии производства сыра отсутствует дополнительная специальная операция по устранению или гидролизу лактозы. При изготовлении традиционных видов сыров гидролиз лактозы является частью комплексных биохимических преобразований, происходящих в процессе их производства [32].

Содержание лактозы

Таблица 1

в некоторых молочных продуктах [30,31]

\begin{tabular}{|c|c|c|}
\hline \multirow{2}{*}{ Продукт } & \multicolumn{2}{|c|}{$\begin{array}{l}\text { Массовая доля } \\
\text { лактозы, \% }\end{array}$} \\
\hline & по [30] & по [31] \\
\hline Сыры сычужные твердые и полутвердые и зрелые & 0 & - \\
\hline $\begin{array}{c}\text { Сыры сычужные мягкие: камамбер 45,0\% } \\
\text { моцарелла }\end{array}$ & - & $\begin{array}{l}0,1-1,8 \\
0,1-3,1\end{array}$ \\
\hline $\begin{aligned} & \text { Масло сладкосливочное: } \text { Традиционное м. д. ж. } 82,5 \% \\
& \text { Крестьянское м. д. ж. } 72,5 \%\end{aligned}$ & $\begin{array}{l}0,8 \\
1,3\end{array}$ & $\stackrel{0,6}{-}$ \\
\hline $\begin{array}{ll}\text { Творог: } & \text { жирный м. Д. ж. 18,0\% } \\
& \text { полужирный м. Д. ж. 9,0\% } \\
& \text { нежирный м. д. ж. 0,6\% }\end{array}$ & $\begin{array}{l}2,8 \\
3,0 \\
3,3\end{array}$ & $\begin{array}{l}2,7 \\
- \\
3,2\end{array}$ \\
\hline $\begin{aligned} \text { Сметана: м. д. ж. } 20 \% \\
\text { м. д. ж. } 10 \%\end{aligned}$ & $\begin{array}{l}3,4 \\
3,9\end{array}$ & - \\
\hline $\begin{array}{ll}\text { Сливки: } & \text { м. д. ж. 20,0\% } \\
& \text { м. д. ж. 10,0\% }\end{array}$ & $\begin{array}{l}4,0 \\
4,5\end{array}$ & $\begin{array}{l}- \\
-\end{array}$ \\
\hline $\begin{aligned} \text { Молоко: } & \text { м. д. ж. 3,2\% } \\
& \text { м. д. ж. } 1,5 \%\end{aligned}$ & $\begin{array}{l}4,7 \\
4,8\end{array}$ & $\begin{array}{l}4,8 \\
4,9\end{array}$ \\
\hline $\begin{array}{l}\text { м. д. ж. } 3,2 \% \\
\text { м. д. ж. } 1,5 \%\end{array}$ & $\begin{array}{l}3,5 \\
5,9\end{array}$ & $\overline{4,1}$ \\
\hline $\begin{array}{r}\text { Молоко сгущенное стерилизованное: м. д. ж. } 7,8 \% \\
\text { м. д. ж. 10,0\% }\end{array}$ & $\begin{array}{c}10,3 \\
-\end{array}$ & $\overline{12,5}$ \\
\hline $\begin{array}{l}\text { Сухие молочные консервы: } \\
\text { сливки сухие м. д. ж. } 42,0 \% \\
\text { молоко сухое цельное м. д. ж. } 25,0 \% \\
\text { молоко сухое нежирное м. д. ж. 1,0\% } \\
\text { сыворотка сухая }\end{array}$ & $\begin{array}{l}30,2 \\
39,3 \\
52,6 \\
-\end{array}$ & $\begin{array}{c}- \\
- \\
- \\
70,0\end{array}$ \\
\hline
\end{tabular}

Количество лактозы в различного вида сырах определяется спецификой технологии их изготовления. Зависит как от количественного и качественного состава используемой бактериальной закваски, так и от срока созревания сыров. К примеру, в сыре Голландском, имеющем полный срок созревания 60 суток и производимом по технологии сыров с низкой температурой второго нагревания, лактоза полностью сбраживается уже к 10-15 суткам созревания. В сыре Российском, относящемся к группе сыров с повышенным уровнем молочнокислого брожения, лактоза полностью сбраживается или присутствует в следовых количествах по истечении 10 суток созревания. В сыре Чеддер, также относящемся к группе сыров с повышенным уровнем молочнокислого брожения, половина всего количества лактозы сбраживается уже в течение 6 часов прессования, а в Эмментальском лактоза присутствует всего лишь в следовых количествах через 4 часа после прессования и полностью сбраживается уже к 5 суткам созревания [33].
Те же изменения претерпевает лактоза в процессе производства кислосливочного масла, когда существенная ее часть сбраживается под действием заквасочной микрофлоры и трансформируется в летучие и нелетучие вкусо-ароматические вещества, формирующие характерный для этого вида масла вкус и аромат. Напротив, технология производства традиционных видов сладкосливочного масла обеспечивает содержание лактозы в готовом продукте на уровне 0,8-1,3\% в зависимости от массовой доли жира продукта.

Масло сладкосливочное Традиционное с массовой долей жира 82,5\%, где содержание лактозы составляет лишь 0,6-0,8\%, вполне можно отнести к категории низколактозных продуктов, поскольку, в соответствии с Техническим регламентом Таможенного союза «О безопасности молока и молочной продукции» ТР ТС 033/2013, низколактозным продуктом считается продукт, содержание лактозы в котором составляет не более $1 \%$.

При производстве сливочного масла из-за высокого содержания в нем жира и, соответственно, невысокого содержания сухих обезжиренных веществ основная часть лактозы переходит сначала в обезжиренное молоко, а затем в пахту при сепарировании.

Безлактозное сливочное масло, содержание лактозы в котором должно составлять не более $0,01 \%$, можно получить только из безлактозного молока (сливок), для чего в технологический процесс производства должна быть включена дополнительная операция по снижению содержания молочного сахара в используемом исходном сырье. Это возможно путем ферментативного расщепления данного соединения либо путем сочетания чистого молочного жира и безлактозной молочной плазмы, которая может быть получена из обезжиренного молока методом ультрафильтрации в сочетании с ферментацией специфическими ферментами.

Диетотерапия является основным методом лечения лактазной недостаточности. Человек, страдающий этим недугом, без ущерба для здоровья может употреблять в пищу лишь те молочные продукты, содержание лактозы в которых снижено или, в лучшем случае, полностью отсутствует. Для крайней непереносимости лактозы требуется исключительно молоко без лактозы. Но большинство людей с гиполактазией, если им дать соответствующие рекомендации, могут переносить некоторые продукты, содержащие лактозу, без симптомов. Общепризнано, что молоко с пониженным содержанием лактозы на 50-80\% удовлетворяет физиологические потребности большинства групп с непереносимостью лактозы [34].

Иногда употребление свободных от лактозы продуктов необходимо во время приема антибиотиков, поскольку способность кишечника расщеплять молочный сахар в этот период может быть снижена.

Решение вопроса об употреблении людьми с лактазной недостаточностью молочных продуктов без негативных последствий для своего здоровья заключается в развитии ассортимента и производстве низко- и безлактозной молочной продукции. В США и многих европейских странах в последние годы в значительной степени выросли продажи таких продуктов по причине растущего осознания существования непереносимости лактозы у части потребителей. В России в настоящее время также отмечается положительная тенденция по увеличению производства и расширению ассортимента низко- и безлактозных молочных продуктов. Это в совокупности с доступностью побуждает потребителей делать выбор в пользу таких продуктов [35].

Одним из первых производителей, уделивших внимание проблеме лактазной недостаточности у людей и их питанию, стала финская молочная компания Valio, несмотря на то, что в Финляндии непереносимостью лактозы страдает всего лишь около 17\% населения. Проводившиеся с начала 1970-х годов 
исследования в этом направлении позволили компании создать большое разнообразие молочных продуктов с гидролизованной лактозой. В 1978 г. компания Valio выпустила в продажу безлактозное сухое молоко. После чего ассортимент продуктов с низким содержанием молочного сахара стал постепенно развиваться, и к 1985 г. он значительно расширился [36].

Согласно информации, освещенной в докладе DSM Global Insight 2016 года [unpublished data], большинство потребителей безлактозных молочных продуктов Колумбии и Китая позиционируют данную продукцию как продукцию категории здорового питания, не всегда принимая во внимание основное ее назначение (несмотря на то, что эти страны отличаются гораздо более высоким уровнем непереносимости лактозы, чем, например, Финляндия). 82\% китайцев и 73\% жителей Колумбии считают, что безлактозные молочные продукты более привлекательны для здоровья, нежели аналогичные традиционные молочные продукты. Также респонденты этих стран указали, что увеличили бы объемы потребления безлактозных молочных продуктов при условии снижения в них массовой доли жира и количества сахара.

На сегодняшний день в странах Западной Европы и Латинской Америки рынок безлактозных молочных продуктов - это самый динамично развивающийся сегмент молочной промышленности. Ожидается, что оборот безлактозной молочной продукции к 2022 году достигнет 9 миллиардов евро и будет превышать общий объем молочной продукции (7,3\% против $2,3 \%)$. Самой значимой категорией в сегменте безлактозных молочных продуктов, занимающей две трети рынка, является питьевое молоко. Следующая по востребованности категория - безлактозный йогурт. Также высокий рост производства отмечен и в категории безлактозных сыров [29,37].

Крупнейшими производителями безлактозных молочных продуктов на мировом рынке являются компании: Green Valley Creamery (США), McNeil Nutritionals, LLC (США), Valio International (Финляндия), Alpro (Бельгия), Arla Foods amba (Дания), Cabot Creamery Cooperative (США), Saputo Dairy Products (Канада), The Danone Company Inc. (Франция), Dean Foods (США), Smith Dairy Products Co. (США), Granarolo Group (Италия), Mondelez International (США).

Наряду с крупными промышленными предприятиями отдельные фермерские хозяйства часто полностью переходят на производство безлактозных молочных продуктов [38].

Для этого они используют нейтральную $\beta$-галактозидазу, полученную из молочных дрожжей Kluyveromyces lactis (или Saccharomyces lactis, K. marxianus или K. fragilis). Данный фермент производится европейской компанией DSM Food Specialties (Нидерланды) под торговой маркой Maxilact ${ }^{\circledR}$, а также тремя компаниями Японии: Godo, Amano и Nagase, продающими свою продукцию через посредников под разными торговыми марками [39].

В Российской Федерации низко- и безлактозные молочные продукты производятся с 1970-х годов при помощи ферментативного гидролиза, позволяющего устранить до 98\% лактозы $[40,41]$.

Обычно лактозу расщепляют посредством внесения в исходное сырье безопасного и пригодного для применения в пищевой промышленности фермента лактазы, искусственно получаемого из грибов Aspergillus niger и Aspergillus oryzae или дрожжей Kluyveromyces fragilis и Kluyveromyces lactis [42]. Существуют два вида лактаз: кислотостойкие и нейтральные, которые работают при разных уровнях $\mathrm{pH}$ : менее 5,7 и более 5,7 соответственно.

Преимуществом ферментативного расщепления молочного сахара можно считать сохранение состава исходного сырья, так как прибегать к внесению посторонних добавок не требуется. К недостаткам данного метода можно отнести изменение органолептических свойств продукта, а именно: появление избыточной сладости (избыток почти вдвое), обусловленной вкусовыми свойствами моносахаридов, на которые расщепляется лактоза. Этот недостаток в большей мере относится к питьевому молоку. Однако стоит отметить, что усиление сладости молока в результате гидролиза лактозы в странах Латинской Америки и Азии не рассматривается как недостаток, но не приветствуется в Северной Европе и Северной Америке [29].

Альтернативным способом получения безлактозных молочных продуктов с естественным (без избытка сладости) вкусом являются ультра- и нанофильтрация [37,43]. Данные технологии позволяют удалять значительную часть лактозы, после чего остатки молочного сахара подвергаются ферментативному гидролизу при помощи лактазы. Ввиду практически полного исключения молочного сахара из продуктов, произведенных с применением ультрафильтрации, их могут употреблять люди с алактазией, а также страдающие диабетом. Недостатком технологии производства безлактозных продуктов методом ультрафильтрации является ее низкая производительность, достаточно сложная воспроизводимость, а также потеря части минеральных веществ и других растворимых низкомолекулярных элементов молока с отделяемой сывороткой (пермеат). Восстановление минерального состава молока после ультрафильтрации возможно путем внесения минеральных и витаминных добавок [44].

Наиболее совершенным, но в то же время дорогостоящим методом получения безлактозного молока является комбинированный метод производства, который позволяет в значительной степени сохранить исходный солевой баланс продукта. Этот метод предусматривает ферментативный гидролиз лактозы, ультрафильтрацию ферментированного молока с получением УФ-концентрата и нанофильтрацию полученного пермеата. В результате нанофильтрации пермеат разделяется на углеводный концентрат, содержащий продукты гидролиза (лактоза, глюкоза галактоза), и пермеат, очищенный от углеводов. Последний смешивают с УФ-концентратом и направляют на дальнейшую технологическую обработку $[45,46]$.

Китайскими учеными [47] запатентован способ производства низколактозного питьевого или сухого молока. Способ заключается в том, что в молоко при перемешивании добавляются молочный коагулянт и кальциевая соль для получения молочного сгустка. Молочный сгусток нагревается, разрезается с перемешиванием до отделения сыворотки. Частицы сгустка растворяются молочным растворителем для получения повторно растворенного молока. Низколактозную жидкую или сухую сыворотку получают методом мембранного разделения. Повторно растворенное молоко смешивают с низколактозной сывороткой с добавлением или без добавления молочного жира, эмульгируют с помощью эмульгатора для получения безлактозного молока. Затем полученное низколактозное молоко гомогенизируют и пастеризуют. В дальнейшем его могут подвергать сушке для получения сухого низколактозного молока. По данным авторов, указанный способ позволяет снизить содержание лактозы в продукте на 50\% (до 2,3-2,5\%).

Авторы изобретения полагают, что данный метод является эффективным для получения молока, предназначенного для употребления в пищу людьми с лактазной недостаточностью. Считается, что при снижении содержания лактозы в молочных продуктах на 20-50\% симптомы ее непереносимости у людей маловероятны, что не противоречит Национальному стандарту Китайской Народной Республики GB13432-2004, согласно которому расфасованный специализированный продукт, содержащий $\leqslant 0,5 \%$ сахара (включая моно- и дисахариды), считается безлактозным продуктом; содержащий $\leqslant 2,5 \%$ - низколактозным [47]. 
В Российской Федерации безлактозная молочная продукция достаточно широко представлена в сегменте продуктов для кормления грудных детей $[13,48]$. Для питания взрослого населения и детей школьного возраста, страдающих лактазной недостаточностью, производится низко- и безлактозное питьевое молоко. Его изготавливают такие крупные предприятия, как молочный комбинат «Останкинский», молочный комбинат «Ставропольский», семейный агропромышленный холдинг «Братья Чебурашкины», фирмы «Лактовит» и Parmalat, а также группа компаний «Лосево».

На российском рынке можно встретить безлактозное молоко с массовой долей жира 2,5\% - продукцию республики Беларусь под торговой маркой «Савушкин продукт» [49], а также низколактозное молоко питьевое ультрапастеризованное с массовой долей жира 1,8\% торговой марки «Село зеленое» (ОАО «Милком», Удмуртская республика). На молочном комбинате «Ставропольский» производят низколактозное молоко Finnlat с массовой долей жира 2,5\% и 3,5\%, молоко стерилизованное низколактозное $(0,5 \%$ и $2,5 \%)$, а также безлактозное мороженое. Молочный комбинат «Останкинский» изготавливает низколактозное молоко под торговой маркой Latter с массовой долей жира 1,5\%, безлактозное сливочное масло с массовой долей жира 82,5\% (технология основана на включении в состав масла в процессе производства фермента лактазы), а Белгородский молочный комбинат - низколактозное молоко Parmalat Low Lactose с массовой долей жира 1,8\%.

Безлактозное молоко можно производить двумя способами: периодическим и асептическим [50]. Оба метода основаны на гидролизе лактозы ферментом лактаза.

При периодическом способе лактазу вносят в резервуар с сырым или пастеризованным молоком в начале технологического процесса и выдерживают при температуре $6 \pm 2{ }^{\circ} \mathrm{C}$ в течение 24 ч при постоянном медленном перемешивании для предотвращения отстаивания жира. После чего молоко пастеризуют, гомогенизируют и фасуют в потребительскую тару.

При асептическом способе молоко сначала подвергают ультра-высокотемпературной обработке, затем непосредственно перед упаковкой в потребительскую тару вносят необходимую дозу фермента лактазы [51]. Этот способ производства приобрел популярность в последние годы, но применим только к безлактозному УВТ-молоку, т. к. технология его производства предусматривает выдержку готовой продукции перед реализацией трое суток. За это время лактоза в молоке полностью гидролизуется. А при создании пастеризованного молока продукт отправляется в торговую сеть сразу после упаковки. При таком способе производства лактоза, содержащаяся в продукте, не успевает гидролизоваться до употребления его в пищу. Поэтому безлактозное пастеризованное молоко таким способом не производят.

В странах Северной Европы и Северной Америки безлактозное УВТ-молоко чаще получают асептическим методом производства с предварительным удалением основного количества лактозы ультрафильтрацией, поскольку для населения этих стран, традиционно употребляющих в пищу молоко, усиление сладости продукта является нежелательным фактором [29]. Напротив, при производстве сладких йогуртов эффект увеличения сладости при ферментативном гидролизе лактозы рассматривается как преимущество. Это позволяет снизить количество добавляемой сахарозы в среднем на $1,5-2$ г/100 г [52].

Ассортимент низко- и безлактозных продуктов продолжает развиваться и совершенствоваться. Кроме низко- и безлактозного молока и продуктов для детского питания [53], а также безлактозного сливочного масла, на рынке появились низколактозные кисломолочные продукты [35,54], в том числе питьевой йогурт Latter безлактозный с массовой долей жира 2,5\%, бифидойогурт питьевой «Активиа» безлактозный с массовой долей жира 1,5\%, а также ферментированный низколактозный молочный продукт [55] и низколактозный высокобелковый замороженный десерт на козьем молоке [56].

При производстве безлактозного йогурта возможно использование как кислотостойких, так и нейтральных лактаз. Но следует учитывать, что нейтральная лактаза полностью инактивируются при достижении $\mathrm{pH}$ менее 5,5 уже через 2,53 часа выдержки. Этого времени обычно не хватает для полного устранения из продукта лактозы, поэтому доза вносимого фермента должна быть выше, чем при производстве безлактозного молока. Надежным способом полного устранения лактозы при производстве безлактозного йогурта является выдержка молока с внесенной в него лактазой перед пастеризацией. Возможно также одновременное внесение фермента лактазы и йогуртовой культуры уже после пастеризации молока [57].

Таким образом, как следует из приведенных материалов, на рынке молочных продуктов появляется все больше различных продуктов с низким содержанием лактозы, спрос на которые растет. Это связано с повышением информированности и заинтересованности в таких продуктах части населения, страдающего лактазной недостаточностью.

\section{2. Методические аспекты контроля остаточного содержания лактозы в низко- и безлактозных молочных продуктах}

Учитывая серьезность проблемы непереносимости лактозы отдельными категориями людей, анализ на присутствие лактозы в продуктах питания должен быть в статусе рутинного. С этой целью целесообразно применение простых методов, таких как поляриметрический, метод Бертрана, феррицианидный, йодометрический. Однако эти методы не позволяют обнаружить содержание остаточной лактозы в продуктах с низким содержанием углеводов. Для этого необходимы высокочувствительные аналитические методы, позволяющие определять остаточное количество лактозы в продукте при ее концентрации менее $0,01 \%$. Методы должны быть специфичны, т. к. во время производства молочных продуктов лактоза и иные сахариды в молоке преобразуются термически либо ферментативно во множество различных производных, которые могут затруднять определение количественного содержания лактозы [58,59,60,61].

Как один из наиболее простых методов, удовлетворяющих условиям обнаружения лактозы в низких концентрациях, заслуживает внимания ферментативный метод определения лактозы и галактозы в молоке и молочных продуктах в присутствии других сахаров. По данному методу обнаружение углеводов составляет до 0,1 г/100 г для лактозы и до 0,05 г/100 г для галактозы. Метод предусматривает проведение гидролиза лактозы с помощью фермента $\beta$-галактозидазы до глюкозы и галактозы, окисление имеющейся в пробе галактозы (свободная галактоза плюс образовавшаяся при гидролизе лактозы) в присутствии фермента $\beta$-галактозодегидрогеназа и фотометрическое измерение массовой доли образовавшегося соединения, эквивалентной массовой доле галактозы. По разности оптических плотностей данного раствора и раствора, используемого при определении свободной галактозы, проводят расчет массовой доли лактозы и галактозы [58].

Как правило, ферментативные методы чаще всего измеряют высвобожденную глюкозу после гидролиза лактозы $\beta$-галактозидазой. Такой метод зачастую проблемно использовать для низко- и безлактозных молочных продуктов из-за высокого уровня моносахаридов, образующихся под воздействием лактазы в процессе производства. Для преодоления этой проблемы D. Gille, B. Walther, R. Badertscher and etc. [61] предложили удалять глюкозу, содержащуюся в продукте до 
внесения $\beta$-галактозы путем окисления ее глюкозооксидазой до глюконата. Впоследствии глюкоза, высвобожденная после гидролиза $\beta$-галактозой, определялась количественно с высокой чувствительностью, что привело к пределу обнаружения 0,024 г/кг.

Авторы считают, что разработанный ими ферментативный метод хорошо подходит для обнаружения низкого уровня лактозы в различных молочных продуктах. Кроме того, это исследование подтвердило, что все созревшие сыры по своей природе не содержат молочного сахара, а исследованные в данной работе продукты, заявленные как безлактозные, имели уровни содержания данного вещества ниже 0,1\%, за исключением одного, концентрация лактозы в котором составляла 1,4 г/кг [61].

Иного мнения придерживаются A. Trani, G. Gambacorta and etc. [62], которые провели сравнение ферментативного метода, реализованного с помощью двух ферментных наборов, с двумя альтернативными хроматографическими методами: ВЭЖХ в сочетании с детектором RI и тандемная масс-спектрометрия UPLC (UHPLC-MS/MS). В исследовании использовалось несколько образцов UHT-молока, содержащего разные уровни лактозы. Результаты исследования показали, что ферментативные методы, а также ВЭЖХ в сочетании с детектором RI не подходят для количественного определения остаточной лактозы в безлактозном молоке. По мнению авторов, их следует применять только к обычному молоку. Наилучшие результаты были получены методом жидкостной хроматографии с масс-спектрометрическим детектированием, основанным на использовании аддукта формиата лактозы. Метод оказался очень чувствительным и обеспечил воспроизводимые результаты даже при самых низких концентрациях лактозы.

Для определения низкого уровня лактозы существуют более точные аналитические методы - это высокоэффективная жидкостная хроматография (ВЭЖХ) и высокоэффективная анионообменная хроматография (HPAEC) с импульсным амперометрическим детектированием (PAD) [63].

ВЭЖХ остается одним из наиболее широко используемых методов. Он используется для разделения большого количества углеводов, особенно в пищевых продуктах. ВЭЖХ позволяет напрямую определять углеводы, поскольку они могут поглощать ультрафиолетовые волны с низкой длиной волны. Для разделения углеводов доступно несколько хроматографических методов, наибольшее распространение получили системы с обращенной фазой и катионный обмен. Разделение в распределительной хроматографии с обращенной фазой основано на принципе гидрофобных взаимодействий, происходящих из сил отталкивания между относительно полярными растворителями, неполярными аналитами и неполярными неподвижными фазами. Традиционная адсорбционная хроматография почти повсеместно была заменена ионообменной хроматографией. Углеводы разделяются по разнице зарядов с использованием двух типов ионообменников - анионного и катионного, где соединения заряжены отрицательно и положительно соответственно [63,64].

A. Garballo-Rubio, J. Soto-Chinchilla, and etc. [65] разработали новый метод определения остаточной лактозы в безлактозных молочных продуктах с использованием жидкостной хроматографии в сочетании с тройным квадруполем тандемной массспектрометрии. Для этого была использована хроматография гидрофильного взаимодействия. В качестве оптимальной была выбрана амидная хроматографическая колонка с щелочной подвижной фазой. Кроме того, была разработана быстрая, экономичная и надежная обработка проб для повседневного использования в аналитических лабораториях. Метод был подтвержден с использованием калибровочных стандартов, соответствующих матрице, и анализа восстановления на образце безлактозного молока, полученном гидролизом лактазы обычного молока. Описанный метод был применен к нескольким безлактозным продуктам, и результаты показали, что уровни лактозы в них не всегда ниже рекомендованного максимального значения 100 мг/л.

Более чувствительным методом по сравнению с ВЭЖХ является высокоэффективная анионообменная хроматография с импульсным амперометрическим детектированием (HPAEC-PAD), с помощью которой были определены концентрации лактозы, глюкозы и галактозы в твердом сыре Grana Padano, которые были ниже 1 мг/100 г сыра [65]. Исследование долго созревающего сыра показало, что содержание лактозы естественным образом снизилось с примерно 4,7 г/100 г (в молоке) до 0,5 мг/100 г (в сыре). Было отмечено, что в отличие от молочных продуктов без лактозы или с пониженным содержанием лактозы, полученных путем добавления $\beta$-галактозидазы, в сыре Grana Padano галактоза и глюкоза полностью метаболизируются. Авторы делают вывод о том, что настоящий сыр Grana Padano можно безопасно включать в рацион людей, страдающих непереносимостью лактозы. Кроме того, возможно введение этого сыра в рацион людей, страдающих галактоземией [66].

W. B. van Scheppingen, P. H van Hilten and etc. [59] модифицировали метод HPAEC-PAD в части пробоподготовки с целью эффективного выделения лактозы из матрицы продукта. Метод предусматривает подготовку пробы для анализа путем разбавления, центрифугирования и ультрафильтрации. Анализ HPAEC-PAD на колонке CarboPac PA100 позволил получить хорошее отделение лактозы от других сахаридов. Это разделение в сочетании с детектором PAD дает селективный и чувствительный метод количественного определения при требуемых концентрациях лактозы в молочных продуктах с низким содержанием лактозы.

E. Churakova, K. Peri and etc. [60] сравнили анализ лактозы с помощью HPAEC-PAD с девятью другими широко используемыми методами анализа и пришли к выводу, что только биосенсор лактозы Biomilk300 (Biolan) имеет сопоставимую чувствительность и точность при всех протестированных пониженных концентрациях лактозы, включая 0,01\%. Другие испытанные методы (HPLC-RI, ЯMP, ферментные наборы, криоскопия) не подходят для измерения концентрации лактозы в молоке с низким содержанием лактозы, полученном ферментативным гидролизом.

F. Conzuelo, M. Gamella and etc. [67] разработан метод количественного определения лактозы с применением интегрированного амперометрического биосенсора. Метод основан на гидролизе лактозы до D-галактозы и D-глюкозы, которые окисляются кислородом в присутствии ферментов путем разбавления буферного раствора до заданного рН, чтобы концентрация лактозы в образце соответствовала линейному диапазону калибровочного графика. Эта ферментативная реакция вызывает амперометрический сигнал, пропорциональный концентрации лактозы. Биосенсорный метод не зависит от присутствия в продукте различных сахаров, витаминов, спиртов, ароматизаторов и других соединений; он устойчив к изменениям температуры окружающей среды, температуры образца и объема образца.

Для биосенсорного анализа лактозы в различных безлактозных или низколактозных молочных продуктах, молочных смесях и детских смесях используются различные наборы, содержащие в своем составе лактазы различного происхождения [67,68,69]. Для установления эффективности действия этих наборов группа заинтересованных сторон АОАС по стратегическим методам анализа пищевых продуктов проводит сравнительные исследования образцов молока и молочных продуктов, содержащих низкие уровни лактозы, с помощью 
биосенсорных методов и аккредитованной высокоэффективной анионообменной хроматографии с импульсным амперометрическим детектированием. На основе результатов этих исследований утверждены Стандартные требования к эффективности биосенсорных методов (SMPR ${ }^{\circledR}$ ) 2018.009 для лактозы в молоке с низким ее содержанием или безлактозном, молочных продуктах и продуктах, содержащих молочные ингредиенты. Метод LactoSensR рекомендовано принять как официальный метод АОАС первого действия [68].

Следует отметить, что ферментные амперометрические биосенсоры могут эксплуатироваться неквалифицированным персоналом. Следовательно, их можно рассматривать как привлекательную альтернативу другим, более сложным методам для небольших производств. Тем не менее, мы считаем возможным использовать в статусе стандартизованного арбитражного метода высокоэффективную жидкостную хроматографию (ВЭЖХ) с масс-спектрометрическим детектированием, а также высокоэффективную анинообменную хроматографию с импульсным амперометрическим детектированием (HPAEC-PAD).

В заключение обзора методов, применяемых для обнаружения остаточного содержания лактозы в безлактозных продуктах и контроля за содержанием лактозы в низколактозных продуктах, следует упомянуть метод, основанный на спектроскопии комбинационного рассеяния света - рамановскую спектроскопию. Этот метод был применен китайскими исследователями M. Li, J. Chen, J. Xu, S. Fu, H. Gong [70] для быстрого определения лактозы в молоке и идентификации молочных продуктов с низким ее содержанием. Метод позволяет определять уровень лактозы в диапазоне от 0,028 до 0,1 моль/л с пределом обнаружения 0,019 моль/л.

\section{3. Заключение}

В последние годы ассортимент низко- и безлактозных молочных продуктов значительно вырос, а технологии их производства постоянно совершенствуются.

Представленное разнообразие методов определения остаточной лактозы в безлактозных молочных продуктах говорит об актуальности этой проблемы. Работы в этом направлении ведутся в разных странах с использованием различных подходов, направленных на создание и совершенствование высокочувствительных методов, позволяющих идентифицировать и количественно определять лактозу и продукты ее гидролиза на низких пределах обнаружения.

Молочная промышленность имеет потребность в методах анализа для определения лактозы в молоке и молочных продуктах с низким ее содержанием, а также в безлактозных продуктах. В связи с этим целесообразно использование в статусе международного стандартного контрольного метода анализа для определения лактозы в низко- и безлактозных молочных продуктах высокоэффективную жидкостную хроматографию (ВЭЖХ) с масс-спектрометрическим детектированием, а также высокоэффективную анионообменную хроматографию с импульсным амперометрическим детектированием (HPAEC-PAD).

\section{БИБЛИОГРАФИЧЕСКИЙ СПИСОК}

1. Marangoni, F., Pellegrino, L., Verduci, E., Ghiselli, A., Bernabei, R., Calvani, R. et al. (2019). Cow's milk consumption and health: A health Professional's guide. Journal of the American College of Nutrition, 38(3), 197208. https://doi.org/10.1080/07315724.2018.1491016

2. Тепел, А. (2012). Химия и физика молока. Санкт-Петербург: Профессия, 2012.

3. Foroutan, A., Guo, A. C., Vazquez-Fresno, R., Lipfert, M., Zhang, L., Zheng, J. et al. (2019). Chemical composition of commercial cow's milk. Journal of Agricultural and Food Chemistry, 67(17), 4897-4914. https://doi. org/10.1021/acs.jafc. 9 b00204

4. Alessio, D. R. M., Thaler Neto, A., Velho, J. P., Perreira, I. B., Miquelluti, D. J., Knob, D. A. et al. (2016). Multivariate analysis of lactose content in milk of Holstein and Jersey cows1. Semina: Ciências Agrárias, 37(4Supl.1), 2641-2652. https://doi.org/10.5433/1679-0359.2016v37n4supl1p2641

5. Темирдашева, К.А., Гукежев, В.М. (2016). Зависимость содержания лактозы в молоке коров черно-пестрой породы от различных факторов. Вестник ИрГСХА, 74, 96-101.

6. Синельников, Б.М., Храмцов, А.Г., Евдокимов, И.А., Рябцева, С.А., Серов, А.В. (2007). Лактоза и ее производные. Санкт-Петербург: Профессия, 2007.

7. Sgambat, K., Banks, M., Moudgil, A. (2013). Effect of galactose on glomerular permeability and proteinuria in steroid-resistant nephrotic syndrome. Pediatric Nephrology, 28(11), 2131-2135. https://doi.org/10.1007/ s00467-013-2539-z

8. Ficicioglu, C., Hussa, C., Gallagher, P. R., Thomas, N., Yager, C. (2010). Monitoring of biochemical status in children with duarte galactosemia: Utility of galactose, galactitol, galactonate, and galactose 1-phosphate. Clinical Chemistry, 56(7), 1177-1182. https://doi.org/10.1373/ clinchem.2010.144097

9. Lau, K. K., Wyatt, R. J., Moldoveanu, Z., Tomana, M., Julian, B. A., Hogg, R. J. et al. (2007). Serum levels of galactose-deficient IgA in children with IgA nephropathy and henoch-schönlein purpura. Pediatric Nephrology, 22(12), 2067-2072. https://doi.org/10.1007/s00467-007-0623-y

10. Abrams, S. A., Griffin, I. J., Davila, P. M. (2002). Calcium and zinc absorption from lactose-containing and lactose-free infant formulas. American Journal of Clinical Nutrition, 76(2), 442-446. https://doi.org/10.1093/ ajcn/76.2.442

11. Heine, R. G. (2013). Cow's-milk allergy and lactose malabsorption in infants with colic. Journal of Pediatric Gastroenterology and Nutrition, 57(SUPPL.1), S25-S27. https://doi.org/10.1097/01.mpg.0000441930.13307.9b

12. Щербак, В.А., Щербак, Н.М. (2011). Лактазная недостаточность у детей. Педиатрическая фармакология, 8(3), 90-93.

13. Корниенко, Е.А., Митрофанова, Н.И., Ларченкова, Л.В. (2006). Лактазная недостаточность у детей раннего возраста. Вопросы современной педиатрии, 5(4), 82-86.
14. Leonardi, M., Gerbault, P., Thomas, M. G., Burger, J. (2012). The evolution of lactase persistence in europe. A synthesis of archaeological and genetic evidence. International Dairy Journal, 22(2), 88-97. https://doi. org/10.1016/j.idairyj.2011.10.010

15. Kuokkanen, M., Kokkonen, J., Enattah, N. S., Ylisaukko-Oja, T., Komu, H., Varilo, T. et al. (2006). Mutations in the translated region of the lactase gene (LCT) underlie congenital lactase deficiency. American Journal of Human Genetics, 78(2), 339-344. https://doi.org/10.1086/500053

16. Vilotte, J. -L. (2002). Lowering the milk lactose content in vivo: Potential interests, strategies and physiological consequences. Reproduction Nutrition Development, 42(2), 127-132. https://doi.org/10.1051/rnd:2002012

17. Демина, И.А., Макарова, Е.А. (10 апреля 2020). Безопасность и этика использования трансгенных животных. Материалы научно-практической конференции с международным участием, посвященной 105 -летию со дня рождения А. Г. Банникова. Москва, Россия.

18. Maksimenko, O.G., Deykin, A.V., Khodarovich, YU. M., Georgiev, P.G (2013). Use of transgenic animals in biotechnology: prospects and problems. Acta Naturae, 5-1(16), 33-45.

19. Houdebine, L. -M. (2005). Use of transgenic animals to improve human health and animal production. Reproduction in Domestic Animals, 40(4), 269-281. https:/doi.org/10.1111/j.1439-0531.2005.00596.x

20. Law, D., Conklin, J., Pimentel, M. (2010). Erratum: Lactose intolerance and the role of the lactose breath test. American Journal of Gastroenterology, 105(10), 2308. https://doi.org/10.1038/ajg.2010.146

21. Бельмер, С.В., Мухина, Ю.Г., Чубарова, А. И. Гераськина, В.П., Гасилина, Т.В. (2005). Непереносимость лактозы у детей и взрослых. Леча щий врач, 1, 34-38.

22. Brown-Esters, O., Mc Namara, P., Savaiano, D. (2012). Dietary and biological factors influencing lactose intolerance. International Dairy Journal, 22(2), 98-103. https://doi.org/10.1016/j.idairyj.2011.09.010

23. Артюхова, С.И., Сыксин, С.В. (2014). Распространение гиполактазии среди мирового населения. Динамика систем, механизмов и машин, 6, 62-66.

24. Parker, A. M., Watson, R. R. (2017). Lactose Intolerance. Chapter in book: Nutrients in Dairy and Their Implications on Health and Disease. University of Arizona, Tucson, AZ, United States, 205-211. https://doi. org/10.1016/b978-0-12-809762-5.00016-4

25. Enattah, N. S., Sahi, T., Savilahti, E., Terwilliger, J. D., Peltonen, L., Järvelä, I. (2002). Identification of a variant associated with adult-type hypolactasia. Nature Genetics, 30(2), 233-237. https://doi.org/10.1038/ng826

26. Heyman, M. B. (2006). Lactose intolerance in infants, children, and adolescents. Pediatrics, 118(3), 1279-1286. https://doi.org/10.1542/ peds.2006-1721

27. Боровик, Т.Э., Скворцова, В.А., Рославцева, Е.А., Яцык, Г.В., Лукоянова, О.Л., Степанова, Т.Н. и др. (2004). Лактазная недостаточность 
у детей и возможности её диетической коррекции. Вопросы современной педиатрии, 3(3), 76-81.

28. Зиатдинова, Н.В., Файзуллина, Р.А. (2010). Лактазная недостаточность у детей. Практическая медицина. 3(42), 44-47.

29. Dekker, P. J. T., Koenders, D., Bruins, M. J. (2019). Lactose-free dairy products: Market developments, production, nutrition and health benefits. Nutrients, 11(3), Article 551. https://doi.org/10.3390/nu11030551

30. Скурихин, И.М. (2002). Химический состав российских пищевых продуктов: Справочник. Москва: ДеЛи принт, 2002.

31. Шлейп, Т. (2004). Осторожно: лактоза! Когда молочный сахар несовместим со здоровьем. Санкт-Петербург: Весь, 2004.

32. Мордвинова, В.А., Лепилкина, О.В.(2016). Безлактозные сыры - миф или реальность? Сыроделие и маслоделие, 1, 38-40.

33. Upreti, P., McKay, L. L., Metzger, L. E. (2006). Influence of calcium and phosphorus, lactose, and salt-to-moisture ratio on cheddar cheese quality: Changes in residual sugars and water-soluble organic acids during ripening. Journal of Dairy Science, 89(2), 429-443. https://doi.org/10.3168/ jds.s0022-0302(06)72107-5

34. 34 Ruiz-Matute, A. I., Corzo-Martínez, M., Montilla, A., Olano, A., Copovi, P., Corzo, N. (2012). Presence of mono-, di- and galactooligosaccharides in commercial lactose-free UHT dairy products. Journal of Food Composition and Analysis, 28(2), 164-169. https://doi.org/10.1016/j.jfca.2012.06.003

35. Тихомирова, Н.А., Нгуен, Б.Т. (2020). Низколактозные кисломолочные продукты. Переработка молока, 10(252), 10-12.

36. Jelen, P., Tossavainen, O. (2003). Low lactose and lactose-free milk and dairy products - prospects, technologies and applications. Australian Journal of Dairy Technology, 58(2), 161-165.

37. Harju, M., Kallioinen, H., Tossavainen, O. (2012). Lactose hydrolysis and other conversions in dairy products: Technological aspects. International Dairy Journal, 22(2), 104-109. https://doi.org/10.1016/j.idairyj.2011.09.011

38. Pulinas, L., Spanu, C., Idda, I., Ibba, I., Nieddu, G., Virdis, S. et al. (2017). Production of farmstead lactose-free pecorino di osilo and ricotta cheeses from sheep's milk. Italian Journal of Food Safety, 6(1), 33-39, Article 6353. https:/doi.org/10.4081/ijfs.2017.6353

39. Dekker, P.J.T. (2016). Enzymes Exogenous to Milk in Dairy Technology: $\beta$-d-Galactosidase. Chapter in a book: Encyclopedia of Dairy Sciences: Second Edition. DSM Food-Specialties, Delft, Netherlands 1-8.

40. Добриян, Е.И., Ильина, А.М., Горлова, А.Г. (2019). Получение функциональных продуктов на основе ферментативного гидролиза лактозы. Пищевая промышленность, 4, 36-37. https:/doi.org/10.24411/02352486-2019-10017

41. Остроумов, Л.А., Гаврилов, В.Г. (2013). Биотрансформация лактозы ферментными препаратами $\beta$-галактозидазы. Техника и технология пищевых производств, 1(28), 26А-31.

42. Букуру, Л.К., Скворцов, Е.В., Багаева, Т.В., Канарская, 3.А. (2017). Эффективность применения $\beta$-галактозидазы для получения низколактозного напитка на основе молочной сыворотки. Вестник технологического университета. 20(13), 117-119.

43. Минин, П.С., Тимкин, В.А. (2019). Технология производства безлактозного молока с применением баромембранных процессов. Переработка молока, 12(242), 52-53.

44. Чумакова, И.В., Донская, Г.А. (2020). Изменение состава и физикохимических свойств молочного сырья при производстве безлактозного молока. Известия Оренбургского государственного аграрного университета, 4(84), 193-197. https://doi.org/10.37670/2073-08532020-84-4-193-197

45. Гаврилов, Г.Б., Кравченко, Э.Ф., Гаврилов, В.Г. (2013). Мембранные процессы для переработки молока и сыворотки. Сыроделие и маслоделие, 6, 22-23.

46. Гаврилов, Г.Б., Кравченко, Э.Ф., Гаврилов, В.Г. (2012) Биомембранные процессы. Молочная промышленность , 7, 49-51.

47. Пат. № 2443116. Способ производства безлактозного молока / Янь И., Ван Г., Као М., Янь И. Опубл. 27.02.2012.

48. Тихомирова, Н.А. (2016). Низколактозные и безлактозные продукты детского и лечебного питания. Переработка молока, 3(197), 16-19.

49. Бань, М.Ф., Кириленко, Н.М. (2016, 4 ноября). Тенденции развития рынка безлактозного молока в республике Беларусь. Сборник научных статей международной научно-практической конференции. Гомель, Беларусь.

50. Troise, A. D., Bandini, E., De Donno, R., Meijer, G., Trezzi, M., Fogliano, V. (2016). The quality of low lactose milk is affected by the side proteolytic activity of the lactase used in the production process. Food Research International, 89, 514-525. https://doi.org/10.1016/j.foodres.2016.08.021

51. Dahlqvist, A., Asp, N. G., Burvall, A., Rausing, H. (1977). Hydrolysis of lactose in milk and whey with minute amounts of lactase. Journal of Dairy Research, 44(3), 541-548. https://doi.org/10.1017/s0022029900020495
52. McCain, H. R., Kaliappan, S., Drake, M. A. (2018). Invited review: Sugar reduction in dairy products. Journal of Dairy Science, 101(10), 8619-8640. https://doi.org/10.3168/jds.2017-14347

53. Сафронова, А.И., Коновалова, Л.С., Гурченкова, М.А. (2012). Современные подходы к адаптации молочных смесей для детей раннего возраста. Вопросы современной педиатрии, 11(2), 56-61.

54. Шуляк, Т.Л., Гуща, Н.Ф. (2019). Новые низколактозные кисломолочные продукты с функциональными ингредиентами. Переработка молока, 12(242), 28-31.

55. Анцыперова, М.А., Арсеньева, Т.П., Волкова, О.В., Яковченко, Н.В. (2019, 13-15 ноября). Исследование процесса ферментации при производстве низколактозной молочной продукции. IX Международная научно-техническая конференция. Санкт-Петербург, Россия.

56. Арсеньева, Т.П., Лугова, М.В. (2020). Моделирование низколактозного высокобелкового замороженного десерта на козьем молоке. Colloquium-journal, 19-1(71), 31-34. https://doi.org/10.24411/25206990-2020-12044

57. Karnyaczki, Z., Csanadi, J. (2017). Texture profile properties, sensory evaluation, and susceptibility to syneresis of yoghurt prepared from lactose-free milk. Acta Alimentaria, 46(4), 403-410. https://doi. org/10.1556/066.2016.0018

58. Лепилкина, О.В. (2020). Руководителям лабораторий. Методы определения массовой доли лактозы в молоке и молочных продуктах. Молочная промышленность, 7, 44-45.

59. van Scheppingen, W. B., van Hilten, P. H., Vijverberg, M. P., Duchateau, A. L. L. (2017). Selective and sensitive determination of lactose in lowlactose dairy products with HPAEC-PAD. Journal of Chromatography $B$ : Analytical Technologies in the Biomedical and Life Sciences, 1060, 395-399. https://doi.org/10.1016/j.jchromb.2017.06.024

60. Churakova, E., Peri, K., Vis, J. S., Smith, D. W., Beam, J. M., Vijverberg, M. P. et al. (2019). Accurate analysis of residual lactose in low-lactose milk: Comparing a variety of analytical techniques. International Dairy Journal, 96, 126-131. https://doi.org/10.1016/j.idairyj.2019.02.020

61. Gille, D., Walther, B., Badertscher, R., Bosshart, A., Brügger, C., Brühlhart, M. et al. (2018). Detection of lactose in products with low lactose content. International Dairy Journal, 83, 17-19. https://doi.org/10.1016/j idairyj.2018.03.003

62. Trani, A., Gambacorta, G., Loizzo, P., Cassone, A., Fasciano, C., Zambrini, A. V. et al. (2017). Comparison of HPLC-RI, LC/MS-MS and en zymatic assays for the analysis of residual lactose in lactose-free milk. Food Chemistry, 233, 385-390. https://doi.org/10.1016/j.foodchem.2017.04.134

63. Gambelli, L. (2017). Milk and Its Sugar-Lactose: A Picture of Evaluation Methodologies. Beverages, 3(4), 35. https://doi.org/10.3390/beverages3030035

64. Рыбакова, Е. В. (2005). Высокоэффективная ионная и жидкостная хроматография для анализа продуктов питания для детей. Пищевая промышленность, 3, 24-26.

65. Garballo-Rubio, A., Soto-Chinchilla, J., Moreno, A., Zafra-Gómez, A. (2018). Determination of residual lactose in lactose-free cow milk by hydrophilic interaction liquid chromatography (HILIC) coupled to tandem mass spectrometry. Journal of Food Composition and Analysis, 66, 39-45. https://doi.org/10.1016/j.jfca.2017.11.006

66. Monti, L., Negri, S., Meucci, A., Stroppa, A., Galli, A., Contarini, G. (2017) Lactose, galactose and glucose determination in naturally "lactose free" hard cheese: HPAEC-PAD method validation. Food Chemistry, 220, 18-24. https://doi.org/10.1016/j.foodchem.2016.09.185

67. Conzuelo, F., Gamella, M., Campuzano, S., Ruiz, M. A, Reviejo, A. I., Pingarrón, J. M. (2010). An integrated amperometric biosensor for the determination of lactose in milk and dairy products. Journal of Agricultural and Food Chemistry, 58(12), 7141-7148. https://doi.org/10.1021/if101173e

68. Halbmayr-Jech, E., Kittl, R., Weinmann, P., Schulz, C., Kowalik, A., Sygmund, C. et al. (2021). Determination of lactose in lactose-free and lowlactose milk, milk products, and products containing dairy ingredients by the LactoSens ${ }^{\circledR} \mathrm{R}$ amperometry method: First action 2020.01. Journal of AOAC International, 103(6), 1534-1546. https://doi.org/10.1093/jaoacint/ qsaa080

69. Ivory, R., Delaney, E., Mangan, D., McCleary, B. (2020). Determination of Lactose Concentration in Low-Lactose and Lactose-Free Milk, Milk Products, and Products Containing Dairy Ingredients: Single Laboratory Validation of an Enzymatic Method, First Action Method. Journal of AOAC International. https://doi.org/10.1093/jaoacint/qsab032

70. Li, M., Chen, J., Xu, J., Fu, S., Gong, H. (2015). Determination of lactose in milk by Raman spectroscopy. Analytical Letters, 48(8), 1333-1340. https://doi.org/10.1080/00032719.2014.979358

\section{REFERENCES}

1. Marangoni, F., Pellegrino, L., Verduci, E., Ghiselli, A., Bernabei, R., Calvani, R. et al. (2019). Cow's milk consumption and health: A health Professional's guide. Journal of the American College of Nutrition, 38(3), 197208. https://doi.org/10.1080/07315724.2018.1491016

2. Tepel, A. (2012). Chemistry and physics of milk. Saint Petersburg: Profession, 2012. (In Russian)
3. Foroutan, A., Guo, A. C., Vazquez-Fresno, R., Lipfert, M., Zhang, L., Zheng, J. et al. (2019). Chemical composition of commercial cow's milk. Journal of Agricultural and Food Chemistry, 67(17), 4897-4914. https://doi. org/10.1021/acs.jafc.9b00204

4. Alessio, D. R. M., Thaler Neto, A., Velho, J. P., Perreira, I. B., Miquelluti, D. J., Knob, D. A., da Silva, C. G.. (2016). Multivariate analysis of 
lactose content in milk of Holstein and Jersey cows1. Semina: Ciências Agrárias, 37(4Supl.1), 2641-2652. https://doi.org/10.5433/16790359.2016v37n4supl1p2641

5. Temirdasheva, K.A., Gukezhevb V.M. (2016). Dependence of lactose in the milk of cows of black-pied breed on various factors. Vestnik IRGSHA, 74, 96-101. (In Russian)

6. Sinelnikov, B. M., Khramtsov, A. G., Evdokimov, I. A., Ryabtseva, S. A., Serov, A.V. (2007). Lactose and its derivatives. Saint Petersburg: Profession, 2007. (In Russian)

7. Sgambat, K., Banks, M., Moudgil, A. (2013). Effect of galactose on glomerular permeability and proteinuria in steroid-resistant nephrotic syndrome. Pediatric Nephrology, 28(11), 2131-2135. https://doi.org/10.1007/ s00467-013-2539-z

8. Ficicioglu, C., Hussa, C., Gallagher, P. R., Thomas, N., Yager, C. (2010). Monitoring of biochemical status in children with duarte galactosemia: Utility of galactose, galactitol, galactonate, and galactose 1-phosphate. Clinical Chemistry, 56(7), 1177-1182. https://doi.org/10.1373/ clinchem.2010.144097

9. Lau, K. K., Wyatt, R. J., Moldoveanu, Z., Tomana, M., Julian, B. A., Hogg, R. J. et al. (2007). Serum levels of galactose-deficient IgA in children with IgA nephropathy and henoch-schönlein purpura. Pediatric Nephrology, 22(12), 2067-2072. https://doi.org/10.1007/s00467-007-0623-y

10. Abrams, S. A., Griffin, I. J., Davila, P. M. (2002). Calcium and zinc absorption from lactose-containing and lactose-free infant formulas. American Journal of Clinical Nutrition, 76(2), 442-446. https://doi.org/10.1093/ ajcn/76.2.442

11. Heine, R. G. (2013). Cow's-milk allergy and lactose malabsorption in infants with colic. Journal of Pediatric Gastroenterology and Nutrition, 57(SUPPL.1), S25-S27. https://doi.org/10.1097/01.mpg.0000441930.13307.9b

12. Sherbak, V.A., Sherbak, N.M. (2011). Lactase deficiency in children. Pediatric Pharmacology, 8 (3), 90-93. (In Russian)

13. Kornienko, E.A., Mitrofanova, N.I., Larchenkova, L.V. (2006). Lactase deficiency in babies and infants. Current Pediatrics (Moscow), 5(4), 82-86 (In Russian)

14. Leonardi, M., Gerbault, P., Thomas, M. G., Burger, J. (2012). The evolution of lactase persistence in europe. A synthesis of archaeological and genetic evidence. International Dairy Journal, 22(2), 88-97. https://doi. org/10.1016/j.idairyj.2011.10.010

15. Kuokkanen, M., Kokkonen, J., Enattah, N. S., Ylisaukko-Oja, T., Komu, H., Varilo, T. et al. (2006). Mutations in the translated region of the lactase gene (LCT) underlie congenital lactase deficiency. American Journal of Human Genetics, 78(2), 339-344. https://doi.org/10.1086/500053

16. Vilotte, J. -L. (2002). Lowering the milk lactose content in vivo: Potential interests, strategies and physiological consequences. Reproduction Nutrition Development, 42(2), 127-132. https://doi.org/10.1051/rnd:2002012

17. Demina, I. A., Makarova, E. A. (2020, 24 April). Safety and ethics of using transgenic animals. Materials of the scientific and practical conference with international participation dedicated to the 105th anniversary of the birth of A. G. Bannikov. Moscow: Russia. (In Russian)

18. Maksimenko, O.G., Deykin, A.V., Khodarovich, YU. M., Georgiev, P.G (2013). Use of transgenic animals in biotechnology: prospects and problems. Acta Naturae, 5-1(16), 33-45.

19. Houdebine, L. -M. (2005). Use of transgenic animals to improve human health and animal production. Reproduction in Domestic Animals, 40(4), 269-281. https:/doi.org/10.1111/j.1439-0531.2005.00596.x

20. Law, D., Conklin, J., Pimentel, M. (2010). Erratum: Lactose intolerance and the role of the lactose breath test. American Journal of Gastroenterology, 105(10), 2308. https://doi.org/10.1038/ajg.2010.146

21. Belmer, S.V., Mukhina, Yu.G., Chubarova, A.I., Geraskina, V.P., Gasilina, T.V. (2005). Lactose intolerance in children and adults. The Attending Physician, 1, 34-38. (In Russian)

22. Brown-Esters, O., Mc Namara, P., Savaiano, D. (2012). Dietary and biological factors influencing lactose intolerance. International Dairy Journal, 22(2), 98-103. https://doi.org/10.1016/j.idairyj.2011.09.010

23. Artyukhova, S.I., Syksin, S.V. (2014). Distribution of hypolactasia among the world population. Dynamics of Systems, Mechanisms and Machines, 6, 62-66. (In Russian)

24. Parker, A. M., Watson, R. R. (2017). Lactose Intolerance. Chapter in a book: Nutrients in Dairy and Their Implications on Health and Disease. University of Arizona, Tucson, AZ, United States, 205-211. https://doi. org/10.1016/b978-0-12-809762-5.00016-4

25. Enattah, N. S., Sahi, T., Savilahti, E., Terwilliger, J. D., Peltonen, L., Järvelä, I. (2002). Identification of a variant associated with adult-type hypolactasia. Nature Genetics, 30(2), 233-237. https://doi.org/10.1038/ng826

26. Heyman, M. B. (2006). Lactose intolerance in infants, children, and adolescents. Pediatrics, 118(3), 1279-1286. https://doi.org/10.1542/ peds.2006-1721

27. Borovik, T.E., Skvortsova, V.A., Roslavtseva, E.A., Yatsyk, G.V., Lukoyanova, O.L., Stepanova, T.N. et al. (2004). Lactase deficiency in children and possibilities of its dietary correction. Current Pediatrics (Moscow), 3(3), 76-81. (In Russian)

28. Ziatdinova, N.V., Faizullina, R.A. (2010). Lactase deficiency at children. Practical Medicine. 3(42), 44-47. (In Russian)

29. Dekker, P. J. T., Koenders, D., Bruins, M. J. (2019). Lactose-free dairy products: Market developments, production, nutrition and health benefits. Nutrients, 11(3), Article 551. https://doi.org/10.3390/nu11030551
30. Skurikhin, I.M. (2002). Chemical Composition of Russian Food Products: A Handbook. Moscow: DeLi Print, 2002 (In Russian)

31. Shleip, T. (2004). Caution: lactose! When milk sugar is incompatible with health. Saint Petersburg: Ves, 2004.(In Russian)

32. Mordvinova, V.A., Lepilkina, O.V. (2016). Lactose-free cheeses - myth or reality? Cheese and Butter Making, 1, 38-40. (In Russian)

33. Upreti, P., McKay, L. L., Metzger, L. E. (2006). Influence of calcium and phosphorus, lactose, and salt-to-moisture ratio on cheddar cheese quality: Changes in residual sugars and water-soluble organic acids during ripening. Journal of Dairy Science, 89(2), 429-443. https://doi.org/10.3168/ jds.s0022-0302(06)72107-5

34. Ruiz-Matute, A. I., Corzo-Martínez, M., Montilla, A., Olano, A., Copovi, P., Corzo, N. (2012). Presence of mono-, di- and galactooligosaccharides in commercial lactose-free UHT dairy products. Journal of Food Composition and Analysis, 28(2), 164-169. https://doi.org/10.1016/j.jfca.2012.06.003

35. Tikhomirova, N.A., Nguyen, B.T. (2020). Low-lactose fermented milk products. Milk Processing, 10(252), 10-12. (In Russian)

36. Jelen, P., Tossavainen, O. (2003). Low lactose and lactose-free milk and dairy products - prospects, technologies and applications. Australian Journal of Dairy Technology, 58(2), 161-165.

37. Harju, M., Kallioinen, H., Tossavainen, O. (2012). Lactose hydrolysis and other conversions in dairy products: Technological aspects. International Dairy Journal, 22(2), 104-109. https://doi.org/10.1016/j.idairyj.2011.09.011

38. Pulinas, L., Spanu, C., Idda, I., Ibba, I., Nieddu, G., Virdis, S. et al. (2017). Production of farmstead lactose-free pecorino di osilo and ricotta cheeses from sheep's milk. Italian Journal of Food Safety, 6(1), 33-39, Article 6353. https:/doi.org/10.4081/ijfs. 2017.6353

39. Dekker, P.J.T. (2016). Enzymes Exogenous to Milk in Dairy Technology: $\beta$-d-Galactosidase. Chapter in a book: Encyclopedia of Dairy Sciences: Second Edition. DSM Food-Specialties, Delft, Netherlands 1-8.

40. Dobriyan, E.I., Ilyina, A.M., Gorlova, A.G. (2019). The manufacture of functional products based on lactose fermentative hydrolysis. Food Industry, 4, 36-37. https:/doi.org/10.24411/0235-2486-2019-10017 (In Russian)

41. Ostroumov, L.A., Gavrilov, V.G. (2013). Biotransformation of lactose enzyme preparations $\beta$-galactosidase. Food Processing: Techniques and Technology, 1(28), 26A-31. (In Russian)

42. Bukuru, L.K., Skvortsov, E.V., Bagaeva, T.V., Kanarskaya, Z.A. (2017). Efficiency of $\beta$-galactosidase application for obtaining a low-lactose drink based on milk whey. Technological University Bulletin. 20(13), 117-119. (In Russian)

43. Minin, P.S., Timkin, V.A. (2019). Technology for the production of lactose-free milk using baromembrane processes. Milk processing, 12(242), 52-53. (In Russian)

44. Chumakova, I.V., Donskaya, G.A. (2020). Changes in the composition and physical and chemical properties of raw milk in the production of lactose-free milk. Bulletin of the Orenburg State Agrarian University, 4 (84), 193-197. https://doi.org/10.37670/2073-0853-2020-84-4-193-197 (In Russian)

45. Gavrilov, G.B., Kravchenko, E.F., Gavrilov, V.G. (2013). Membrane processes for processing milk and whey. Cheese and butter making, 6, 22-23. (In Russian)

46. Gavrilov, G.B., Kravchenko, E.F., Gavrilov, V.G. (2012). Bio-membrane processes. Dairy Industry, 7, 49-51. (In Russian)

47. Yan I., Van G., Kao M., Yan Y. (2012). Method for the production of lactose-free milk. Patent RF, no.2443116, 2012. (In Russian)

48. Tikhomirova, N.A. (2016). Low-lactose and lactose-free products for children and medical nutrition. Milk processing, 3(197), 16-19. (In Russian)

49. Ban, M.F., Kirilenko, N.M. (2016, November 4). Development trends of the lactose-free milk market in the Republic of Belarus. Collection of scientific articles of the international scientific and practical conference. Gomel, Belarus.(In Russian)

50. Troise, A. D., Bandini, E., De Donno, R., Meijer, G., Trezzi, M., Fogliano, V. (2016). The quality of low lactose milk is affected by the side proteolytic activity of the lactase used in the production process. Food Research International, 89, 514-525. https://doi.org/10.1016/j.foodres.2016.08.021

51. Dahlqvist, A., Asp, N. G., Burvall, A., Rausing, H. (1977). Hydrolysis of lactose in milk and whey with minute amounts of lactase. Journal of Dairy Research, 44(3), 541-548. https://doi.org/10.1017/s0022029900020495

52. McCain, H. R., Kaliappan, S., Drake, M. A. (2018). Invited review: Sugar reduction in dairy products. Journal of Dairy Science, 101(10), 8619-8640. https://doi.org/10.3168/jds.2017-14347

53. Safronova, A.I., Konovalova, L.S., Gurchenkova, M.A. (2012). Modern ap proaches to adaptation of formulas for infants. Current Pediatrics (Moscow), 11(2), 56-61. (In Russian)

54. Shulyak, T.L., Gushcha, N.F. (2019). New low-lactose fermented milk products with functional ingredients. Milk Processing, 12(242), 28-31. (In Russian)

55. Antsyperova, M.A., Arsenyeva, T.P., Volkova, O.V., Yakovchenko, N.V. (2019, November 13-15). Investigation of the fermentation process in the production of low-lactose dairy products. IX International Scientific and Technical Conference. Saint Petersburg: Russia. (In Russian)

56. Arsenyeva, T.P., Lugova, M.V. (2020). Modeling low lactose high protein frozen dessert with goat's milk. Colloquium-journal, 19-1(71), 31-34. https://doi.org/10.24411/2520-6990-2020-12044 (In Russian)

57. Karnyaczki, Z., Csanadi, J. (2017). Texture profile properties, sensory evaluation, and susceptibility to syneresis of yoghurt prepared 
from lactose-free milk. Acta Alimentaria, 46(4), 403-410. https://doi. org/10.1556/066.2016.0018

58. Lepilkina, O. V. (2020). For the heads of the laboratories. Methods for determining the mass fraction of lactose in milk and dairy products. Dairy Industry, 7, 44-45. (In Russian)

59. van Scheppingen, W. B., van Hilten, P. H., Vijverberg, M. P., Duchateau, A. L. L. (2017). Selective and sensitive determination of lactose in lowlactose dairy products with HPAEC-PAD. Journal of Chromatography B: Analytical Technologies in the Biomedical and Life Sciences, 1060, 395-399. https://doi.org/10.1016/i.jchromb.2017.06.024

60. Churakova, E., Peri, K., Vis, J. S., Smith, D. W., Beam, J. M., Vijverberg, M. P. et al. (2019). Accurate analysis of residual lactose in low-lactose milk: Comparing a variety of analytical techniques. International Dairy Journal, 96, 126-131. https://doi.org/10.1016/j.idairyj.2019.02.020

61. Gille, D., Walther, B., Badertscher, R., Bosshart, A., Brügger, C., Brühlhart, M. et al. (2018). Detection of lactose in products with low lactose content. International Dairy Journal, 83, 17-19. https://doi.org/10.1016/j. idairyj.2018.03.003

62. Trani, A., Gambacorta, G., Loizzo, P., Cassone, A., Fasciano, C., Zambrini, A. V. et al. (2017). Comparison of HPLC-RI, LC/MS-MS and enzymatic assays for the analysis of residual lactose in lactose-free milk. Food Chemistry, 233, 385-390. https://doi.org/10.1016/j.foodchem.2017.04.134

63. Gambelli, L. (2017). Milk and Its Sugar-Lactose: A Picture of Evaluation Methodologies. Beverages, 3(4), 35. https://doi.org/10.3390/beverages3030035

64. Rybakova, E.V. (2005). High performance ion and liquid chromatography for the analysis of food products for children. Food Industry, 3, 24-26. (In Russian)
65. Garballo-Rubio, A., Soto-Chinchilla, J., Moreno, A., Zafra-Gómez, A. (2018). Determination of residual lactose in lactose-free cow milk by hydrophilic interaction liquid chromatography (HILIC) coupled to tandem mass spectrometry. Journal of Food Composition and Analysis, 66, 39-45. https://doi.org/10.1016/j.jfca.2017.11.006

66. Monti, L., Negri, S., Meucci, A., Stroppa, A., Galli, A., Contarini, G. (2017). Lactose, galactose and glucose determination in naturally "lactose free" hard cheese: HPAEC-PAD method validation. Food Chemistry, 220, 18-24. https://doi.org/10.1016/j.foodchem.2016.09.185

67. Conzuelo, F., Gamella, M., Campuzano, S., Ruiz, M. A., Reviejo, A. I. Pingarrón, J. M. (2010). An integrated amperometric biosensor for the determination of lactose in milk and dairy products. Journal of Agricultural and Food Chemistry, 58(12), 7141-7148. https://doi.org/10.1021/ jf101173e

68. Halbmayr-Jech, E., Kittl, R., Weinmann, P., Schulz, C., Kowalik, A., Sygmund, C. et al. (2021). Determination of lactose in lactose-free and lowlactose milk, milk products, and products containing dairy ingredients by the LactoSens ${ }^{\circledR} \mathrm{R}$ amperometry method: First action 2020.01. Journal of AOAC International, 103(6), 1534-1546. https://doi.org/10.1093/jaoacint/ qsaa080

69. Ivory, R., Delaney, E., Mangan, D., McCleary, B. (2020). Determination of Lactose Concentration in Low-Lactose and Lactose-Free Milk, Milk Products, and Products Containing Dairy Ingredients: Single Laboratory Validation of an Enzymatic Method, First Action Method. Journal of AOAC International. https://doi.org/10.1093/jaoacint/qsab032

70. Li, M., Chen, J., Xu, J., Fu, S., Gong, H. (2015). Determination of lactose in milk by Raman spectroscopy. Analytical Letters, 48(8), 1333-1340. https://doi.org/10.1080/00032719.2014.979358

\section{СВЕДЕНИЯ ОБ АВТОРАХ}

Принадлежность к организации

Никитина Юлия Владимировна - младший научный сотрудник, отдел физической химии, Всероссийский научно-исследовательский институт маслоделия и сыроделия

152613, Ярославская обл., Углич, Красноармейский бульвар, 19

Тел.:+ 7-910-829-29-30

E-mail: nikitinaj7@mail.ru

ORCID: https://orcid.org/0000-0003-2224-6995

автор для контактов

Топникова Елена Васильевна - доктор технических наук, директор, Всероссийский научно-исследовательский институт маслоделия и сыроделия

152613 , Ярославская обл., Углич, Красноармейский бульвар, 19

Тел.:+7-910-666-93-93

E-mail: topnikova.1@yandex.ru

ORCID: https://orcid.org/0000-0003-0225-6870

Лепилкина Ольга Валентиновна - доктор технических наук, главный научный сотрудник, руководитель отдела физической химии, Всероссийский научно-исследовательский институт маслоделия и сыроделия

152613 , Ярославская обл., Углич, Красноармейский бульвар, 19

Тел.:+7-910-965-51-61

E-mail: lepilkina vniims@mail.ru

ORCID: https://orcid.org/0000-0002-2375-3959

Кашникова Ольга Геннадьевна - младший научный сотрудник, отдел физической химии, Всероссийский научно-исследовательский институт маслоделия и сыроделия

152613 , Ярославская обл., Углич, Красноармейский бульвар, 19

Тел.: + 7-962-200-14-15

E-mail: kachnikova@mail.ru

ORCID: https://orcid.org/0000-0002-7557-6835

Критерии авторства

Авторы в равных долях имеют отношение к написанию рукописи и одинаково несут ответственность за плагиат

\section{Конфликт интересов}

Авторы заявляют об отсутствии конфликта интересов

\section{AUTHOR INFORMATION}

Affiliation

Julia V. Nikitina - junior researcher, Department of Physical Chemistry, All-Russian Scientific Research Institute of Butter- and Cheesemaking 19, Krasnoarmeysky Boulevard, 152613, Yaroslavl Region, Uglich, Russia

Tel.: + 7-910-829-29-30

E-mail: nikitinaj7@mail.ru

ORCID: https://orcid.org/0000-0003-2224-6995

* corresponding author

Elena V. Topnikova - doctor of technical sciences, director, All-Russian Scientific Research Institute of Butter- and Cheesemaking

19, Krasnoarmeysky Boulevard, 152613, Yaroslavl Region, Uglich, Russia

Tel.: + 7-910-666-93-93

E-mail: topnikova.1@yandex.ru

ORCID: https://orcid.org/0000-0003-0225-6870

Olga V. Lepilkina - doctor of technical sciences, chief researcher, head of the Department of Physical Chemistry, All-Russian Scientific Research Institute of Butter- and Cheesemaking

19, Krasnoarmeysky Boulevard, 152613, Yaroslavl Region, Uglich, Russia

Tel.: + 7-910-965-51-61

E-mail: lepilkina_vniims@mail.ru

ORCID: https://orcid.org/0000-0002-2375-3959

Olga G. Kashnikova - junior researcher, Department of Physical Chemistry, All-Russian Scientific Research Institute of Butter- and Cheesemaking 19, Krasnoarmeysky Boulevard, 152613, Yaroslavl Region, Uglich, Russia Tel.: + 7-962-200-14-15

E-mail: kachnikova@mail.ru

ORCID: https://orcid.org/0000-0002-7557-6835

\section{Contribution}

Authors equally relevant to the writing of the manuscript, and equally responsible for plagiarism

Conflict of interest

The authors declare no conflict of interest 